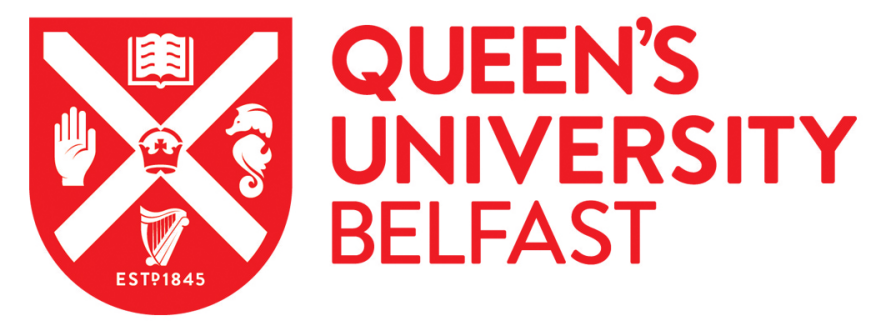

\title{
Salmonella is the most common foodborne pathogen in African food exports to the European Union: Analysis of the Rapid Alert System for Food and Feed (1999-2019)
}

Somorin, Y. M., Odeyemi, O. A., \& Ateba, C. N. (2021). Salmonella is the most common foodborne pathogen in African food exports to the European Union: Analysis of the Rapid Alert System for Food and Feed (1999-2019). Food Control, 123, [107849]. https://doi.org/10.1016/j.foodcont.2020.107849

Published in:

Food Control

Document Version:

Peer reviewed version

Queen's University Belfast - Research Portal:

Link to publication record in Queen's University Belfast Research Portal

\author{
Publisher rights \\ (C) 2020 Elsevier Ltd. \\ This manuscript is distributed under a Creative Commons Attribution-NonCommercial-NoDerivs License \\ (https://creativecommons.org/licenses/by-nc-nd/4.0/), which permits distribution and reproduction for non-commercial purposes, provided the \\ author and source are cited.
}

\section{General rights}

Copyright for the publications made accessible via the Queen's University Belfast Research Portal is retained by the author(s) and / or other copyright owners and it is a condition of accessing these publications that users recognise and abide by the legal requirements associated with these rights.

Take down policy

The Research Portal is Queen's institutional repository that provides access to Queen's research output. Every effort has been made to ensure that content in the Research Portal does not infringe any person's rights, or applicable UK laws. If you discover content in the Research Portal that you believe breaches copyright or violates any law, please contact openaccess@qub.ac.uk. 
3

a School of Pharmacy, Queen's University Belfast, Belfast, United Kingdom

b Office of Research Services, Research Division, University of Tasmania, Launceston, Australia

$9 \quad{ }^{c}$ Food Security and Safety Niche Area, Faculty of Natural and Agricultural Sciences, NorthWest University, Mmabatho, South Africa 


\begin{abstract}
Global food imports, including those from Africa, constitute an integral part of the food chain in the European Union (EU) and a potential source of food hazards. Foodborne pathogens are among the food hazards that do not only impact on public health but also have economic implications for exporters. The Rapid Alert System for Food and Feed (RASFF) is an important tool for reporting and communicating food safety risks among EU Member States and EEA countries. This study aimed to identify the common foodborne pathogens in foods originating from African countries to the EU between 1999 and 2019 by analysing RASFF notifications. A total of 596 notifications were reported by 19 countries due to the presence of pathogenic microorganisms (PM) in food originating from 27 African countries. The highest number of notifications related to Greece $(n=228)$ and most of the PM notifications were border rejections (60.6\%). PM notifications increased from 17 (2016) to 46 (2017) and 173 (2019). Salmonella was the most predominant pathogen notified, accounting for $523(87.8 \%)$ of PM notifications. Over half $(52 \%)$ of the Salmonella notifications were from foods originating from Eastern Africa, followed by Western Africa $(n=145 ; 28 \%)$, and the country with the highest Salmonella contamination was Sudan $(n=182)$. The most important product category contaminated with Salmonella was "nuts, nut products and seeds" $(n=343)$, with majority $(n=335)$ being sesame seeds. Evaluation of the RASFF risk decision listed for each notification showed that $97 \%$ of Salmonella-contaminated sesame seeds posed serious risks to consumers. African countries exporting food products to the EU must strengthen their food safety systems to prevent the huge economic losses resulting from non-compliance with EU food safety standards.
\end{abstract}

Keywords: Foodborne pathogens, food export, trade barrier, RASFF notifications, Africa, food safety regulations 


\section{Introduction}

Globalisation has resulted in the possibility of international trade involving exporting of goods and services across the globe (Prakash, 2014). Goods including food are exported across continents as sources of revenue generation to nations through foreign exchange and job creation (Atici, 2013). Despite these benefits, export of safe food is important due to the impact of unsafe food on public health. This has resulted in the establishment of various food standards and risk communication tools in countries around the world to help preserve public health (Attrey, 2017). The Rapid Alert System for Food and Feed (RASFF) was created in 1979 for the efficient and real time sharing of information regarding food safety among European Union (EU) member states, European Food Safety Authority, and European Commission, thereby leading to prompt actions to mitigate the risks of potential hazards in the food chain that could impact food safety and consumer health (D.'Amico et al., 2018).

Various reasons have been identified for the rejection of export foods by the EU. For example, food allergen has been reported to be one of the reasons for the rejection of food exported to the EU (Pádua, Moreira, Moreira, Melo de Vasconcelos, \& Barros, 2019). The presence of foreign bodies such as insect pests/larvae, glasses, and metals present in fruits, nuts, and other food products was another reported reason for 1446 rejections between 1998 and 2015 (Djekic, Jankovic, \& Rajkovic, 2017). Food fraud was also reported as cause of rejection of food exported to the EU from 2000 to 2003 (Bouzembrak \& Marvin, 2016). Leuschner et al. (2013) reported the presence of biogenic amines as the cause of the rejection of fish products exported to the EU from 2000 to 2010. Pathogenic microorganisms (PM) have also been the basis for rejection of several food products exported from different countries at EU external borders (European Commission, 2020a). Furthermore, PM such as Salmonella, have been reported to contaminate several imported food products and some of them are linked to clinical cases and foodborne disease outbreaks in the UK (McLauchlin et al., 2019). The most commonly reported foodborne pathogens in the EU in terms of confirmed human cases are Campylobacter spp., non-typhoidal Salmonella spp., shigatoxigenic Escherichia coli, Yersinia spp. and Listeria monocytogenes (European Food Safety Authority and European Centre for Disease Prevention and Control, 2019). Over 23 million foodborne illnesses are reported annually in Europe leading to 4,500 deaths and 400,000 disability adjusted life years (DALYs) (World Health Organization, 2017).

The EU is Africa's most important trading partner in goods, with $30.8 \%$ of African exports going to the EU in 2019 (Eurostat, 2020). Food and drink represented $12.7 \%$ of EU's import from Africa in 2019, a value declining from 16.4\% in 2016 (Eurostat, 2020). Food safety is one of the main non-tariff barriers causing restrictions and diminishing trade between Africa and the EU (Kareem, Brümmer, \& Martinez-Zarzoso, 2015). There is dearth of literature on the cause of rejection of food imports originating from Africa at EU borders and whether PM play a significant role in this. In a study on the reasons for 1102 rejections of Africa's food exports to the EU from 2008 to 2013, Kareem et al. (2015) reported that $7.2 \%$ were due to PM, among other reasons such as noncompliance with food safety standards on mycotoxins, pesticide residues, heavy metals, and foreign bodies. The authors showed that non-compliance of African food exports with EU food standards resulted in huge economic losses, although they did not give a comprehensive analysis of the PM involved and the trend of the rejection over the years. Hence, this study aims to investigate the occurrence and prevalence of pathogenic microorganisms in African food exports to the EU and analyse the trends from 1999 to 2019 based on the RASFF.

\section{Methods}

Data were extracted from the RASFF portal version 1.9 (European Commission, 2020b) according to the following search criteria:

1. Notified from: 01/01/1999 
2. Notified till: $31 / 12 / 2019$

3. Hazard category: Pathogenic microorganisms

4. Country flagged as: Origin

5. Country: African countries were searched individually: Algeria, Angola, Benin, Botswana, Burkina Faso, Burundi, Cameroon, Cape Verde, Central African Republic, Chad, Comoros, Congo (Brazzaville), Côte d'Ivoire, Democratic Republic of the Congo, Djibouti, Egypt, Equatorial Guinea, Eritrea, Ethiopia, Gabon, Gambia, Ghana, Guinea, GuineaBissau, Kenya, Lesotho, Liberia, Libya, Madagascar, Malawi, Mali, Mauritania, Mauritius, Morocco, Mozambique, Namibia, Niger, Nigeria, Rwanda, Senegal, Seychelles, Sierra Leone, Somalia, South Africa, Sudan, Swaziland, São Tomé and Príncipe, Tanzania, Togo, Tunisia, Uganda, Western Sahara, Zambia, Zimbabwe. South Sudan is not available as a country in the RASFF database.

Notifications obtained for each country was exported to Microsoft Excel 2016. Notification data $(n=717)$ for all African countries was combined into one Excel spreadsheet and the column headings retained as presented in the RASFF database. Since this study is focussed on pathogenic microorganisms in food products, data related to feed $(n=119)$ and food poisoning cases caused by histamine $(n=1)$ and an unidentified cause $(n=1)$ were excluded from the data. An additional column "Country of origin" was added to the Excel file to facilitate further analysis. The resulting notifications involving food products $(n=596)$ were analysed to determine the notification trends and characteristics (i.e. types, basis, action taken and notifying country); and the pattern of notifications of specific pathogens by food types and country of origin. When data was missing on notification basis and action taken, the phrase "not specified" was used and data presented in tables have been ordered in descending order.

Based on gaps in notifications for some countries in different years, data on trend of Salmonella notifications was aggregated according to geographical regions assigned by the African Union i.e. Eastern Africa (Comoros, Djibouti, Eritrea, Ethiopia, Kenya, Madagascar, Mauritius, Rwanda, Seychelles, Somalia, South Sudan, Sudan, Tanzania and Uganda); Western Africa (Benin, Burkina Faso, Cabo Verde, Côte d'Ivoire, Gambia, Ghana, Guinea, Guinea-Bissau, Liberia, Mali, Niger, Nigeria, Senegal, Sierra Leone and Togo); Southern Africa (Angola, Botswana, Eswatini (formerly known as Swaziland), Lesotho, Malawi, Mozambique, Namibia, South Africa, Zambia and Zimbabwe); Northern Africa (Algeria, Egypt, Libya, Mauritania, Morocco, Sahrawi Republic and Tunisia) and Central Africa (Burundi, Cameroon, Central African Republic, Chad, Congo Republic, DR Congo, Equatorial Guinea, Gabon and São Tomé and Príncipe). Furthermore, in the analysis of Salmonella contamination by food, some food belonging to "obsolete" product categories were reassigned to relevant existing categories as follows: sparrow $(n=1)$ moved to "poultry" from "meat and meat product"; tuna $(\mathrm{n}=1)$ moved to "fish and fish products" from an obsolete group "wild-caught fish"; cuttlefish $(n=2)$ and octopus $(n=7)$ moved to "cephalopods and products" from an obsolete group "molluscs"; clam $(n=2)$ moved to "bivalve molluscs and products" from an obsolete group "molluscs"; snail meat $(n=2)$ moved to "gastropods" from an obsolete group "molluscs".

\section{Results}

\subsection{Notifications of pathogenic microorganisms (PM) in foods from African countries}

A total of 596 notifications were identified in the RASFF database for PM in foods originating from African countries between 1999 and 2019. There were 19 notifying countries with the highest notifications from Greece $(n=228)$, Italy $(n=76)$, Norway $(n=56)$, Germany $(n=55)$ and the Netherlands $(n=51)$ (these five countries reported $78 \%$ of the total notifications). PM notifications for foods from African countries fluctuated between 4 - 19 notifications annually in 1999 - 2016; however, there was a significant increase from 2017 (46) to 2019 (173) (Figure 1). PM notifications in the last three years (2017 - 2019) accounted for $58 \%$ of all reported notifications. 
PM notifications were associated with food products originating from 27 African countries namely: Algeria $(n=3)$, Botswana $(n=27)$, Burkina Faso $(n=9)$, Chad $(n=1)$, Côte d'Ivoire $(n=7)$, Egypt $(n=35)$, Ethiopia $(n=26)$, Ghana $(n=6)$, Guinea $(n=3)$, Kenya $(n=16)$, Madagascar $(n=3)$, Mali $(n=1)$, Mauritania $(n=1)$, Mauritius $(n=1)$, Morocco $(n=14)$, Mozambique $(n=2)$, Namibia $(n=29)$, Niger $(n=1)$, Nigeria $(n=111)$, Senegal $(n=25)$, South Africa $(n=3)$, Sudan $(n=182)$, Swaziland (now known as Eswatini; $n=1)$, Tanzania $(n=14)$, Tunisia $(n=35)$, Uganda $(n=38)$ and Zimbabwe $(n=2)$. The notifications were not evenly distributed among the various product categories. Although 18 product categories were affected, notifications on "nuts, nut products and seeds" ( $n=345)$, "meat and meat products (other than poultry)" ( $n=56)$, "fish and fish products" ( $n=47)$ and "herbs and spices" ( $n=42)$ were most frequently reported. Altogether, these four product categories account for $82 \%$ of the 596 PM notifications.

\subsection{Notification characteristics}

The basis for the notifications included different aspects of border control $(74 \%)$, official control $(11.7 \%)$ and company's own checks $(2.9 \%)$ (Table 1). Some notifications were based on food poisoning outbreaks $(n=5)$ while the basis for $62(10.4 \%)$ notifications were not specified. Notification from company's own checks came from the Netherlands $(n=7)$, Germany $(n=4)$, United Kingdom $(n=3)$, Belgium $(n=2)$ and Portugal $(n=1)$. Most of the PM notifications on food originating from African countries were border rejections $(n=361 ; 60.6 \%)$, alert notifications were $10.7 \%(n=64)$ while others were information notifications (Table 1). Based on the classification prior 2011, 137 notifications were only classified as "information" notification. This was used when a risk has been identified in food or feed placed on the market, but no rapid action is required. In 2011, "information notification" was divided into "information for attention" and "information for follow-up", so in 2011-2019, there were 27 "information for attention" and 7 "information for followup" notifications. Border rejections were $\leq 13$ per year between 2008 and 2016 , but their number increased to 34 in 2017, 118 in 2018 and 165 in 2019. Notifications on food from Sudan $(n=180)$, Nigeria $(n=85)$ and Uganda $(n=29)$ mainly reported as border rejections, predominantly related to "nuts and nut products and seeds". Majority of reported products were "re-dispatched" to the originating country $(n=138 ; 23 \%)$, import was not authorized $(n=127 ; 21 \%)$ or underwent "physical/chemical treatment" ( $\mathrm{n}=81 ; 14 \%)$ (Table 1$)$.

\subsection{Pathogenic microorganisms associated with notifications}

Pathogenic bacteria and viruses were identified in food products from Africa from 1999 to 2019. Salmonella was the most predominant pathogen in foods, accounting for $523(87.8 \%)$ of reported pathogenic microorganisms, followed by Vibrio spp. $(n=21)$, norovirus $(n=20)$, Bacillus cereus $(n=11)$ and Hepatitis $A(n=11)$ (Table 2). Vibrio spp. was reported in shrimps, crab, cuttlefish, shark, octopus, grouper, monktails and hake. Norovirus was reported in raspberries, organic red fruits, cocktail tomatoes, strawberries and clams. B. cereus was found in ginger powder, banku flour, cassava flour, vanilla powder, mopani worms, parsley, fennel seeds, sesame seeds and sweet peppers. Hepatitis A was reported in strawberries, clams, razor shells and dates. Reports on other bacterial pathogens were relatively low including Clostridium spp. $(n=5)$ in rosemary, marjoram, fennel seeds, tapioca flour and shrimps; pathogenic $E$. coli [shigatoxin-producing $E$. coli O104:H4 ( $n=2)$ and enterotoxigenic E. coli O27:H7 $(n=1)]$ in clams, fenugreek seeds and sugar peas; Campylobacter spp. $(\mathrm{n}=2)$ in spring onions and sugar snaps; Cronobacter sakazakii $(n=2)$ in baby foods; L. monocytogenes $(n=1)$ in Nile perch fish; Citrobacter freundii $(n=1)$ in beef and Shigella sonnei $(n=1)$ in sugar peas. Some notifications $(n=5)$ reported co-occurrence of pathogens in foods i.e. Clostridium spp. and Vibrio spp. was reported in shrimps from Tanzania; $V$. cholerae and V. parahaemolyticus in shrimps from Mozambique; L. monocytogenes and Salmonella in fish fillet from Kenya; Salmonella and B. cereus in ground ginger from Nigeria; and shigatoxin-producing E. coli and Salmonella in chilled clam from Tunisia.

\subsection{Salmonella notification in foods originating from Africa}

Salmonella notifications were between 3 and 21 annually from 1999 to 2016 and has increased since 2017. Most of the Salmonella notifications were reported in the last 3 years (2017-2019) $(n=338 ; 68 \%)$. Among 523 Salmonella notifications in foods originating from Africa, over half of 
the foods were from Eastern Africa $(n=271 ; 52 \%)$ with most of them coming from Sudan $(n=182)$. This was followed by Western Africa $(n=145 ; 28 \%)$, with products from Nigeria $(n=101)$ mostly affected; Southern Africa $(n=60 ; 11 \%)$ and Northern Africa $(n=46 ; 9 \%)$ (Figure 1). Chad was the only Central African country with Salmonella notification $(n=1$ in 2019). Salmonella notifications were reported by 17 countries, mainly Greece $(n=227 ; 43.4 \%)$, Norway $(n=55 ; 10.5 \%)$, Germany $(n=51 ; 9.8 \%)$, the Netherlands $(n=47 ; 9 \%)$, Italy $(n=45 ; 8.6 \%)$ and Poland $(n=41 ; 7.8 \%)$.

The most important product categories with Salmonella contamination were "nuts, nut products and seeds" ( $n=343)$; "meat and meat products (other than poultry)" ( $n=56)$; "fish and fish products" $(n=43)$; and "herbs and spices" $(n=35)$ (Table 3). Sesame seeds $(n=335)$ was the main food item contaminated by Salmonella and accounted for $64 \%$ of total Salmonella notifications. Salmonellacontaminated sesame seeds originated from Sudan $(n=182 ; 54.3 \%)$, Nigeria $(n=84 ; 25.1 \%)$, Uganda $(n=29 ; 8.7 \%)$, Ethiopia $(n=26 ; 7.8 \%)$, Burkina Faso $(n=8 ; 2.4 \%)$, Senegal $(n=2 ; 0.6 \%)$ with one notification each from Chad, Egypt, Mali and Tanzania (Figure 2). Only 15 (4\%) Salmonella notifications involving sesame seeds was reported from 1999 to 2016, and majority ( $n=320 ; 96 \%$ ) occurred between 2017 and 2019. Among the five countries of origin with the highest Salmonella notifications in sesame seeds, number of notifications increased since 2017 in three of them (Sudan, Ethiopia and Uganda). Salmonella notifications in sesame seeds reduced from 40 in 2018 to 30 in 2019 for Nigeria while for Burkina Faso, there was no notification in 2019 compared to 3 in 2018. Evaluation of RASFF risk decision listed on each notification showed that the risk posed by Salmonella-contaminated sesame seeds to consumers was "serious" in $97 \%$ of the Salmonella notifications.

\section{Discussion}

This study analysed RASFF data on the notifications of PM in foods from African countries into the EU between 1999 and 2019. PM notifications of foods from African countries increased from $<20$ notifications annually between 1999 and 2016 to 46 in 2017, 128 in 2018 and 173 in 2019 (Figure 1). This growing trend of PM notifications in foods from Africa could be due to, but not limited to climate change (Maggiore, Afonso, Barrucci, \& De Sanctis, 2020). Extreme weather conditions, such as increased ambient temperature, was already significantly associated with increased presence of pathogenic bacteria in foods and foodborne infections (Milazzo et al., 2016; Zhang, Bi, \& Hiller, 2008). Significant rise in temperature has been observed in Africa (Collins, 2011; Federal Ministry of Environment, 2014) and was predicted to increase with progressive climate changes. Higher extreme temperatures exceeding $45^{\circ} \mathrm{C}$ have been experienced in parts of Ethiopia in recent years (National Meteorological Agency, 2019). The highest PM notifications were reported in May (59) and June (71), which corresponds to the warmest months in Sudan, the country with the most Salmonella notifications. Summer temperature peaks have also been associated with increased Salmonella cases in the US (Williams, Ebel, Golden, \& Schlosser, 2014), Iran (Soltan Dallal et al., 2020), Canada (Brubacher et al., 2020) and Australia (Zhang et al., 2008). In addition to climate change, the exponential increase in RASFF notifications resulted from increased official import controls and samples tested and improved reporting systems (Jansen, Grabowski, Gerulat, \& Klein, 2016).

Border rejections constituted the highest number of notifications in foods from Africa. The inability to meet EU food standards have resulted in ban of the food items from entering the EU, which resulted in huge economic losses for the exporting country. For example, dried beans from Nigeria has been banned from import into the EU since 2015 because of the problem of pesticide residues exceeding maximum limits set by the EU (European Commission, 2015). Similar suspension of entry into the EU is in place for betel leaves from Bangladesh due to Salmonella contamination (European Commission, 2020a). Based on known and emerging health risks in certain food products, the EU imposed more official controls at border control posts on selected imported food products (European Commission, 2019). Some of the foods include sesame seeds from Sudan, Nigeria, Ethiopia, Uganda due to Salmonella contamination, which are the main countries affected by Salmonella contamination in the present study (Table 3). Others are melon seeds/egusi (from 
Nigeria and Sierra Leone) and groundnut (from Madagascar and Senegal) due to aflatoxins; sweet pepper from Egypt and beans from Kenya due to pesticide residues; as well as palm oil importation of contaminated and unsafe foods could constitute a significant risk to health and safety of consumers in the EU.

Increasing number of official controls at border posts is the first step towards the ban (suspension of imports) of specific foods into the EU. For example, increasing number of official controls was put in place in 2013 for dried beans from Nigeria due to high levels of pesticide residue (dichlorvos). Due to continuous non-compliance and frequent border rejections, an initial one-year ban was placed on dried beans from Nigeria coming into the EU in 2015 (European Commission, 2015). This ban was extended for the next three years from 2016, due to no improvement in the safety of dried beans and is still currently in force (European Commission, 2020a). This ban results in a significant economic loss within the dried beans value chain in Nigeria, hence the need to develop strategies to control food hazards from the countries of origin. A quality system is currently being developed and implemented for dried beans in Nigeria towards ensuring food safety and return to EU markets (United Nations Industrial Development Organization (UNIDO), 2015). A similar scheme is ongoing in Sudan for the control of Salmonella in sesame (United Nations Industrial Development Organization (UNIDO), 2020). However, there are no evidence of efforts to prevent Salmonella contamination in sesame seeds produced in Nigeria, which is mainly produced for export and is the second most exported agricultural product (National Bureau of Statistics, 2020).

Salmonella was the most common pathogen reported in foods originating from Africa. As an enteric pathogen, the predominance of Salmonella could be attributed to unhygienic practices during food production processes. For example, sesame, the food product most affected by Salmonella contamination, is dried in the field, where it could come in contact with human and animal faeces in the soil. In addition, the hulling process, which involves softening the seeds in warm water, could also serve as a point of Salmonella contamination. Salmonella contamination in hulled sesame seeds poses significant risk to human health because they are often consumed as raw products (Brockmann, Piechotowski, \& Kimmig, 2004). Furthermore, sesame is also processed into other food products, such as tahini and hummus, and Salmonella contamination in these products have been implicated in multi-country outbreaks in Europe and around the world (Meinen et al., 2019; Paine et al., 2014; Unicomb et al., 2005). In the European outbreak in 20162017, the novel Salmonella enterica subsp. enterica serotype (11:z41:e,n,z15) was isolated from sesame seeds that originated from Nigeria and sesame paste from Greece, with raw material from Sudan (Meinen et al., 2019). Based on this and further RASFF alerts, sesame seed from Sudan, Nigeria and Uganda was included into the list of produce for increased level of official controls on imports because of possible Salmonella contamination (European Commission, 2017).

While Salmonella was the most predominant bacteria in foods from Africa, other important foodborne pathogens were also reported. For example, Vibrio spp. was mainly reported in seafoods such as shrimps, crab, cuttlefish, shark, octopus, grouper, monktails and hake. These seafoods are retailed in small to medium-sized ethnic food retail outlets in the EU, mainly in the United Kingdom, France, Italy, the Netherlands and Germany (CBI, 2018), and they are consumed not only by the ethnic African populations but also people of other nationalities. Consumption of raw or undercooked seafood/shellfish contaminated with Vibrio spp. could cause foodborne illness and the contaminated produce could cross-contaminate other food items. While consumption of Vibrio-contaminated foods could potentially result in small clusters of cholera cases, however they are often cooked before consumption, thus reducing the likelihood of disease and the few cases in the EU/EEA countries (European Centre for Disease Prevention and Control, 2019). Vibrio spp. have also been detected in various seafoods (30.9\% to $58.7 \%)$, meat (44.6\%) and poultry products from several African countries (Adeyemi, Enyinnia, Nwanze, Smith, \& Omonigbehin, 2008; Azwai et al., 2016; Ndip, Akoachere, Mokosso, Ndip, \& Anyangwe, 2002). 
$B$. cereus was reported in ginger powder, banku flour, cassava flour, vanilla powder, mopani worms, parsley, fennel seeds, sesame seeds and sweet peppers. These are mainly dried foods and contamination could have been through traditional drying processes, which is often done on bare floors containing soil, potentially facilitating contact with Bacillus spores (Vilain, Luo, Hildreth, \& Brözel, 2006). B. cereus was recently reported in flours from millet $(23.33 \%)$, maize $(30 \%)$ and cassava (40\%) from Côte d'Ivoire (N'Guessan, Bakayoko, Cisse, Dalie, \& Sindic, 2019). Although the notifications on other bacterial foodborne pathogens, such as Campylobacter spp., $L$. monocytogenes and pathogenic E. coli were very few in food originating from Africa, these pathogens are predominant in European food products and caused foodborne outbreaks (European Food Safety Authority and European Centre for Disease Prevention and Control, 2019), therefore, they require continuous monitoring. The presence of foodborne viruses was not limited to shellfish (clam and razor shell) but was also reported in fruit and vegetables (strawberry, raspberry, date and tomatoes) from Africa. Contaminated water used for irrigation is a major vehicle for the transmission of enteric viruses and norovirus. They were detected in water used for drinking and irrigation in South Africa (Sibanda \& Okoh, 2013). Norovirus and Hepatitis A have also been reported in shellfish (clams, mussels and oysters) (Fusco et al., 2019; Le Guyader et al., 2009), fruit (raspberries) (Cook, Williams, \& D'Agostino, 2019) and vegetables (lettuce, rocket and mixed salad) produced in the EU (Terio et al., 2017).

In conclusion, this study showed that Salmonella was the most important foodborne pathogenic microorganism reported in foods exported from Africa to the EU. Most of the cases of Salmonella notifications were in sesame seeds. There were very few notifications regarding Campylobacter spp., L. monocytogenes and pathogenic E. coli. Food quality management and hygienic practices should be established throughout the food supply chain to prevent Salmonella contamination particularly in sesame and dried food products.

\section{References}

Adeyemi, A., Enyinnia, V., Nwanze, R., Smith, S., \& Omonigbehin, E. (2008). Antimicrobial susceptibilty of potentially pathogenic halophilic Vibrio species isolated from seafoods in Lagos, Nigeria. African Journal of Biotechnology, 7(20), 3788-3791.

Atici, C. (2013). Food safety regulations and export responses of developing countries: The case of Turkey's fig and hazelnut exports. FAO Commodity and Trade Policy Research Working Paper No. 39.

Attrey, D. P. (2017). Food safety in international food trade-imports and exports. In R. K. Gupta, P. Dudeja, \& Singh Minhas (Eds.), Food Safety in the 21st Century (pp. 455-468). San Diego: Academic Press.

Azwai, S. M., Alfallani, E. A., Abolghait, S. K., Garbaj, A. M., Naas, H. T., Moawad, A. A., Gammoudi, F. T., Rayes, H. M., Barbieri, I., \& Eldaghayes, I. M. (2016). Isolation and molecular identification of Vibrio spp. by sequencing of 16S rDNA from seafood, meat and meat products in Libya. Open Veterinary Journal, 6(1), 36-43. https://doi.org/10.4314/ovj.v6i1.6

Bouzembrak, Y., \& Marvin, H. J. P. (2016). Prediction of food fraud type using data from Rapid Alert System for Food and Feed (RASFF) and Bayesian network modelling. Food Control, 61, 180-187. https://doi.org/10.1016/j.foodcont.2015.09.026

Brockmann, S. O., Piechotowski, I., \& Kimmig, P. (2004). Salmonella in sesame seed products. Journal of Food Protection, 67(1), 178-180. https://doi.org/10.4315/0362-028X-67.1.178

Brubacher, J., Allen, D. M., Déry, S. J., Parkes, M. W., Chhetri, B., Mak, S., Sobie, S., \& Takaro, T. K. (2020). Associations of five food- and water-borne diseases with ecological zone, land use and aquifer type in a changing climate. Science of the Total Environment, 728, 138808. https://doi.org/10.1016/j.scitotenv.2020.138808

Centre for the Promotion of Imports from developing countries (CBI) (2018). Exporting fish and seafood to the European ethnic retail channels. Minitry of Foreign Affairs, The Netherlands. https://www.cbi.eu/node/1091/pdf 
Collins, J. M. (2011). Temperature variability over Africa. Journal of Climate, 24(14), 3649_ 3666. https://doi.org/10.1175/2011JCLI3753.1

Cook, N., Williams, L., \& D’Agostino, M. (2019). Prevalence of norovirus in produce sold at retail in the United Kingdom. Food Microbiology, 79, 85-89. https://doi.org/10.1016/j.fm.2018.12.003

D.'Amico, P., Nucera, D., Guardone, L., Mariotti, M., Nuvoloni, R., \& Armani, A. (2018). Seafood products notifications in the EU Rapid Alert System for Food and Feed (RASFF) database: Data analysis during the period 2011-2015. Food Control, 93, 241-250. https://doi.org/10.1016/j.foodcont.2018.06.018

Djekic, I., Jankovic, D., \& Rajkovic, A. (2017). Analysis of foreign bodies present in European food using data from Rapid Alert System for Food and Feed (RASFF). Food Control, 79, 143-149. https://doi.org/10.1016/j.foodcont.2017.03.047

European Centre for Disease Prevention and Control. Cholera. In: ECDC. Annual epidemiological report for 2018. Stockholm: ECDC; 2019. https://www.ecdc.europa.eu/sites/default/files/documents/cholera-annual-epidemiologicalreport-2018.pdf

European Commission. (2015). Commission Implementing Regulation (EU) 2015/943 of 18 June 2015. Official Journal of the European Union, 58(L 154), 8.

European Commission. (2017). Commission Implementing Regulation (EU) 2017/1142 of 27 June 2017. Official Journal of the European Union, 60(L 165), 29.

European Commission. (2019). Commission Implementing Regulation (EU) 2019/1793. Official Journal of the European Union, 62(L277), 89.

European Commission. (2020a). Commission Implementing Regulation (EU) 2020/625 of 6 May 2020. Official Journal of the European Union, 63(L 144), 13.

European Commission. (2020b). RASFF portal version 1.9. Retrieved June 29, 2020, from https://webgate.ec.europa.eu/rasff-window/portal/?event=SearchForm\&cleanSearch=1\#

European Food Safety Authority and European Centre for Disease Prevention and Control. (2019). The European Union One Health 2018 Zoonoses Report. EFSA Journal, 17(12), 1276. https://doi.org/10.2903/j.efsa.2019.5926

Eurostat. (2020). Africa-EU - international trade in goods statistics. Retrieved September 11, 2020, from https://ec.europa.eu/eurostat/statistics-explained/index.php/China-EU_international_trade_in_goods_statistics\#EU_and_China_in_world_trade_in_goods

Federal Ministry of Environment. (2014). Nigeria's Second National Communication under the United Nations Framework Convention on Climate Change. Abuja. Retrieved from https://climatechange.gov.ng/wpcontent/uploads/2015/06/NGN.SECOND.NATIONAL.COMMUNICATION5.pdf

Fusco, G., Anastasio, A., Kingsley, D. H., Amoroso, M. G., Pepe, T., Fratamico, P. M., Cioffi, B., Rossi, R., La Rosa, G. \& Boccia, F. (2019). Detection of hepatitis a virus and other enteric viruses in shellfish collected in the Gulf of Naples, Italy. International Journal of Environmental Research and Public Health, 16, 2588; https://doi.org/10.3390/ijerph16142588

Jansen, W., Grabowski, N., Gerulat, B., \& Klein, G. (2016). Food safety hazards and microbiological zoonoses in European meat imports detected in border inspection in the period 2008-2013. Zoonoses and Public Health, 63, 53-61. https://doi.org/10.1111/zph.12204

Kareem, F. O., Brümmer, B., \& Martinez-Zarzoso, I. (2015). Food Safety Standards, Compliance and European Union's Rejection of African Exports: The role of Domestic Factors. GlobalFood Discussion Papers. Göttingen.

Le Guyader, F. S., Parnaudeau, S., Schaeffer, J., Bosch, A., Loisy, F., Pommepuy, M., \& Atmar, R. L. (2009). Detection and quantification of noroviruses in shellfish. Applied and Environmental Microbiology, 75(3), 618-624. https://doi.org/10.1128/AEM.01507-08

Leuschner, R. G. K., Hristova, A., Robinson, T., \& Hugas, M. (2013). The Rapid Alert System for Food and Feed (RASFF) database in support of risk analysis of biogenic amines in food. Journal of Food Composition and Analysis, 29(1), 37-42. https://doi.org/10.1016/j.jfca.2012.09.004 
Maggiore, A., Afonso, A., Barrucci, F., \& De Sanctis, G. (2020). Climate change as a driver of emerging risks for food and feed safety, plant, animal health and nutritional quality. EFSA Supporting Publication (Vol. EN-1881). https://doi.org/10.2903/sp.efsa.2020.en-1881

McLauchlin, J., Aird, H., Andrews, N., Chattaway, M., de Pinna, E., Elviss, N., ... Willis, C. (2019). Public health risks associated with Salmonella contamination of imported edible betel leaves: Analysis of results from England, 2011-2017. International Journal of Food Microbiology, 298, 1-10. https://doi.org/10.1016/j.ijfoodmicro.2019.03.004

Meinen, A., Simon, S., Banerji, S., Szabo, I., Malorny, B., Borowiak, M., \& Hadziabdic, S. (2019). Salmonellosis outbreak with novel Salmonella enterica subspecies enterica serotype attributable to sesame products in five European countries , 2016 to 2017. Eurosurveillance, 24(36), 1800543.

Milazzo, A., Giles, L. C., Zhang, Y., Koehler, A. P., Hiller, J. E., \& Bi, P. (2016). The effect of temperature on different Salmonella serotypes during warm seasons in a Mediterranean climate city, Adelaide, Australia. Epidemiology and Infection, 144, 1231-1240. https://doi.org/10.1017/S0950268815002587

N'Guessan, E., Bakayoko, S., Cisse, M., Dalie, W., \& Sindic, M. (2019). Prevalence of Bacillus cereus and emetic strains detection from Ivory Coast local flours. Agronomie Africaine, 8, $151-159$.

National Bureau of Statistics (2020). Foreign Trade in Goods Statistics - Q2 2020. Abuja, Nigeria.

National Meteorological Agency. (2019). Annual Climate Bulletin for the Year 2019. Addis Ababa, Ethiopia.

Ndip, R. N., Akoachere, J. F. T. K., Mokosso, D. K., Ndip, L. M., \& Anyangwe, I. A. N. (2002). Carriage of Vibrio species by shrimps harvested from the coastal waters of South West Cameroon. East African Medical Journal, 79(3), 146-149.

Pádua, I., Moreira, A., Moreira, P., Melo de Vasconcelos, F., \& Barros, R. (2019). Impact of the regulation (EU) 1169/2011: Allergen-related recalls in the rapid alert system for food and feed (RASFF) portal. Food Control, 98(June 2018), 389-398. https://doi.org/10.1016/j.foodcont.2018.11.051

Paine, S., Thornley, C., Wilson, M., Dufour, M., Sexton, K., Miller, J., King, G., Bell., S., Bandaranayake, D., \& Mackereth, G. (2014). An outbreak of multiple serotypes of Salmonella in New Zealand linked to consumption of contaminated tahini imported from Turkey. Foodborne Pathogens and Disease, 11(11), 887-892. https://doi.org/10.1089/fpd.2014.1773

Prakash, J. (2014). The challenges for global harmonisation of food safety norms and regulations: issues for India. Journal of the Science of Food and Agriculture, 94(10), 19621965. https://doi.org/10.1002/jsfa.6147

Sibanda, T., \& Okoh, A. I. (2013). Real-time PCR quantitative assessment of Hepatitis A virus, rotaviruses and enteroviruses in the Tyume River located in the Eastern Cape Province, South Africa. Water SA, 39(2), 295-304. https://doi.org/10.4314/wsa.v39i2.14

Soltan Dallal, M. M., Ehrampoush, M. H., Aminharati, F., Dehghani Tafti, A. A., Yaseri, M., \& Memariani, M. (2020). Associations between climatic parameters and the human salmonellosis in Yazd province, Iran. Environmental Research, 187, 109706. https://doi.org/10.1016/j.envres.2020.109706

Terio, V., Bottaro, M., Pavoni, E., Losio, M. N., Serraino, A., Giacometti, F., Martella, V., Mottola, A., Di Pinto, A., \& Tantillo, G. (2017). Occurrence of Hepatitis A and E and Norovirus GI and GII in ready-to-eat vegetables in Italy. International Journal of Food Microbiology, 249, 61-65. https://doi.org/10.1016/j.jfoodmicro.2017.03.008

Unicomb, L. E., Simmons, G., Merritt, T., Gregory, J., Nicol, C., Jelfs, P., Kirk, M., Tan, A., Thomson, R., Adamopoulos, J., Little, C. L., Currie, A., \& Dalton, C. B. (2005). Sesame seed products contaminated with Salmonella: Three outbreaks associated with tahini. Epidemiology and Infection, 133(6), 1065-1072. https://doi.org/10.1017/S0950268805004085

United Nations Industrial Development Organization (UNIDO). (2015). Quality Products from Nigeria: The National Quality Infrastructure in Action. Abuja, Nigeria. 
United Nations Industrial Development Organization (UNIDO). (2020). Upgrading the Sudanese Sesame seeds value chain. Retrieved September 9, 2020, from https://open.unido.org/projects/SD/projects/160177\#!

Vilain, S., Luo, Y., Hildreth, M. B., \& Brözel, V. S. (2006). Analysis of the life cycle of the soil saprophyte Bacillus cereus in liquid soil extract and in soil. Applied and Environmental Microbiology, 72(7), 4970-4977. https://doi.org/10.1128/AEM.03076-05

Williams, M. S., Ebel, E. D., Golden, N. J., \& Schlosser, W. D. (2014). Temporal patterns in the occurrence of Salmonella in raw meat and poultry products and their relationship to human illnesses in the United States. Food Control, 35(1), 267-273. https://doi.org/10.1016/j.foodcont.2013.07.016

World Health Organization. (2017). The Burden of Foodborne Diseases in the WHO European Region. Copenhagen, Denmark. Retrieved from http://www.euro.who.int/en/healthtopics/disease-prevention/food-safety/publications/2017/the-burden-of-foodborne-diseasesin-the-who-european-region-2017

Zhang, Y., Bi, P., \& Hiller, J. (2008). Climate variations and salmonellosis transmission in Adelaide, South Australia: A comparison between regression models. International Journal of Biometeorology, 52(3), 179-187. https://doi.org/10.1007/s00484-007-0109-4 
Table 1: RASFF notifications of pathogenic microorganisms in foods originating from Africa between 1999 and $2019(n=596)$

\begin{tabular}{|c|c|c|}
\hline \multirow[t]{2}{*}{ Category } & \multicolumn{2}{|c|}{ Notifications } \\
\hline & Number & Percentage (\%) \\
\hline \multicolumn{3}{|l|}{ Notification basis } \\
\hline Border control - consignment detained & 392 & 65.8 \\
\hline Official control on the market & 70 & 11.7 \\
\hline Not specified & 62 & 10.4 \\
\hline Border control - consignment released & 46 & 7.7 \\
\hline Company's own check & 17 & 2.9 \\
\hline Food poisoning & 5 & 0.8 \\
\hline Border control - consignment under customs & 4 & 0.7 \\
\hline \multicolumn{3}{|l|}{ Notification Type } \\
\hline Border rejection & 361 & 60.6 \\
\hline Information & 137 & 23.0 \\
\hline Alert & 64 & 10.7 \\
\hline Information for attention & 27 & 4.5 \\
\hline Information for follow-up & 7 & 1.2 \\
\hline \multicolumn{3}{|l|}{ Action taken } \\
\hline Re-dispatch & 138 & $23.2 \%$ \\
\hline Import not authorised & 127 & $21.3 \%$ \\
\hline Physical/chemical treatment & 81 & $13.6 \%$ \\
\hline Not specified & 47 & $7.9 \%$ \\
\hline Official detention & 44 & $7.4 \%$ \\
\hline Destruction & 32 & $5.4 \%$ \\
\hline Withdrawal from the market & 29 & $4.9 \%$ \\
\hline Recall from consumers & 14 & $2.3 \%$ \\
\hline Return to consignor & 11 & $1.8 \%$ \\
\hline Product recall or withdrawal & 9 & $1.5 \%$ \\
\hline Prohibition to trade - sales ban & 8 & $1.3 \%$ \\
\hline Informing authorities & 7 & $1.2 \%$ \\
\hline Informing recipient(s) & 7 & $1.2 \%$ \\
\hline Informing consignor & 6 & $1.0 \%$ \\
\hline Withdrawal from recipient(s) & 5 & $0.8 \%$ \\
\hline Detained by operator & 4 & $0.7 \%$ \\
\hline No action taken & 4 & $0.7 \%$ \\
\hline Re-dispatch or destruction & 4 & $0.7 \%$ \\
\hline Reinforced checking & 4 & $0.7 \%$ \\
\hline Seizure & 4 & $0.7 \%$ \\
\hline Distribution on the market (possible) & 3 & $0.5 \%$ \\
\hline No stock left & 3 & $0.5 \%$ \\
\hline Physical treatment - heat treatment & 2 & $0.3 \%$ \\
\hline Placed under customs seals & 1 & $0.2 \%$ \\
\hline Public warning - press release & 1 & $0.2 \%$ \\
\hline Screening sample & 1 & $0.2 \%$ \\
\hline
\end{tabular}


Table 2: Pathogenic microorganisms reported in foods from Africa between 1999 and 2019

\begin{tabular}{lcc}
\hline Pathogens & Number $^{\mathrm{a}}$ & Percentage (\%) $^{-}$ \\
\hline Salmonella spp. & 523 & 87.8 \\
Vibrio spp. & 21 & 3.5 \\
Norovirus & 20 & 3.4 \\
Bacillus cereus & 11 & 1.8 \\
Hepatitis A & 11 & 1.8 \\
Clostridium spp. & 5 & 0.8 \\
Pathogenic E. coli & 3 & 0.5 \\
Campylobacter spp. & 2 & 0.3 \\
Cronobacter sakazakii & 2 & 0.3 \\
Listeria monocytogenes & 1 & 0.2 \\
Citrobacter freundii & 1 & 0.2 \\
Shigella sonnei & 1 & 0.2 \\
aThe total number of pathogens $(\mathrm{n}=601)$ exceeds the total number of notifications $(\mathrm{n}=596)$ \\
because of co-occurrence of pathogens in five cases.
\end{tabular}


Table 3: Salmonella notification in foods from Africa (1999-2019)

\begin{tabular}{|c|c|c|}
\hline Food category & Number & Food items \\
\hline $\begin{array}{l}\text { Nuts, nut products and seeds } \\
(\mathrm{n}=343)\end{array}$ & $\begin{array}{c}335 \\
7 \\
1\end{array}$ & $\begin{array}{l}\text { Sesame seed } \\
\text { Melon seed } \\
\text { Tiger nut }\end{array}$ \\
\hline Fruits and vegetables $(n=4)$ & $\begin{array}{l}1 \\
1 \\
1 \\
1\end{array}$ & $\begin{array}{l}\text { Melon seed } \\
\text { Bitter leaf } \\
\text { Ugu leaves } \\
\text { Cassava flour }\end{array}$ \\
\hline Herbs and spices $(n=35)$ & $\begin{array}{l}6 \\
4 \\
4 \\
2 \\
2 \\
2 \\
2 \\
1 \\
1 \\
1 \\
1 \\
1 \\
1 \\
1 \\
1 \\
1 \\
1 \\
1 \\
1 \\
1\end{array}$ & $\begin{array}{l}\text { Ginger } \\
\text { Basil } \\
\text { Parsley } \\
\text { Curry leaves } \\
\text { Dill } \\
\text { Spearmint } \\
\text { Spice mix } \\
\text { Anise seeds } \\
\text { Chilli powder } \\
\text { Coriander } \\
\text { Crushed senna } \\
\text { Cumin seeds } \\
\text { Fennel seed } \\
\text { Lemon thyme } \\
\text { Maligold flower } \\
\text { Marjoram leaves } \\
\text { Peppercorn } \\
\text { Rosemary } \\
\text { Vanilla powder } \\
\text { Various spices }\end{array}$ \\
\hline $\begin{array}{l}\text { Dietetic foods, food supplements, } \\
\text { fortified foods }(n=2)\end{array}$ & 2 & Moringa powder \\
\hline $\begin{array}{l}\text { Meat and meat products (other than } \\
\text { poultry) }(n=55)\end{array}$ & $\begin{array}{c}53 \\
1 \\
1\end{array}$ & $\begin{array}{l}\text { Beef } \\
\text { Springbuck } \\
\text { Crocodile tail fillet }\end{array}$ \\
\hline $\begin{array}{l}\text { Poultry meat and poultry meat } \\
\text { products }^{b}(n=5)\end{array}$ & $\begin{array}{l}4 \\
1\end{array}$ & $\begin{array}{l}\text { Frozen sparrow } \\
\text { Ostrich fillet }\end{array}$ \\
\hline Fish and fish products ${ }^{c}(n=44)$ & $\begin{array}{l}23 \\
6 \\
3 \\
2 \\
2 \\
2 \\
1 \\
1 \\
1 \\
1 \\
1 \\
1\end{array}$ & $\begin{array}{l}\text { Nile Perch } \\
\text { Sole fish } \\
\text { Tuna } \\
\text { Cynoglossus } \\
\text { Red mullet } \\
\text { Fish (no specific name) } \\
\text { Brotula } \\
\text { Dentex angolensis } \\
\text { Fish fry } \\
\text { Forkbeard } \\
\text { Goldblotch grouper } \\
\text { Grouper }\end{array}$ \\
\hline
\end{tabular}


Table 3 (continued): Salmonella notification in foods from Africa (1999-2019)

\begin{tabular}{|c|c|c|}
\hline Food category & Number & Food items \\
\hline \multirow[t]{3}{*}{ Cephalopods and products $^{d}(n=11)$} & 8 & Octopus \\
\hline & 2 & Cuttlefish \\
\hline & 1 & Squid \\
\hline \multirow[t]{2}{*}{ Crustaceans and products $(n=3)$} & 2 & Shrimps \\
\hline & 1 & Crawfish \\
\hline \multicolumn{3}{|l|}{$\begin{array}{l}\text { Bivalve mollusc and products }{ }^{e} \\
(n=7)\end{array}$} \\
\hline Gastropods $^{f}(n=5)$ & 5 & Snails \\
\hline \multicolumn{3}{|l|}{ Cocoa and cocoa preparations, } \\
\hline \multirow{2}{*}{ coffee and tea $(n=3)$} & 1 & Cocoa beans \\
\hline & 1 & Cocoa mass \\
\hline \multirow[t]{2}{*}{ Cereal and bakery product $(n=2)$} & 1 & Cereal flour \\
\hline & 1 & Brown teff grain \\
\hline Confectionery $(n=1)$ & 1 & $\begin{array}{l}\text { Halawa and tahini } \\
\text { sweets }\end{array}$ \\
\hline Other food product / mixed $(n=1)$ & 1 & Melon seeds/yam flour \\
\hline Prepared dishes and snacks $(n=1)$ & 1 & Goulash \\
\hline $\begin{array}{l}\text { Soups, broths, sauces and } \\
\text { condiments }(n=1)\end{array}$ & 1 & Guacamole \\
\hline
\end{tabular}

a Melon seed is also called "agushie" in Ghana; 'Sparrow $(n=1)$ moved to "poultry" from "meat and meat product"; " Tuna ( $n=1)$ moved to "fish and fish products" from an obsolete group "wildcaught fish"; "Cuttlefish $(n=2)$ and octopus $(n=7)$ moved to "cephalopods and products" from

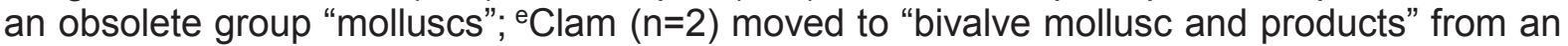
obsolete group "molluscs"; fSnail meat $(n=2)$ moved to "gastropods" from an obsolete group "molluscs" 


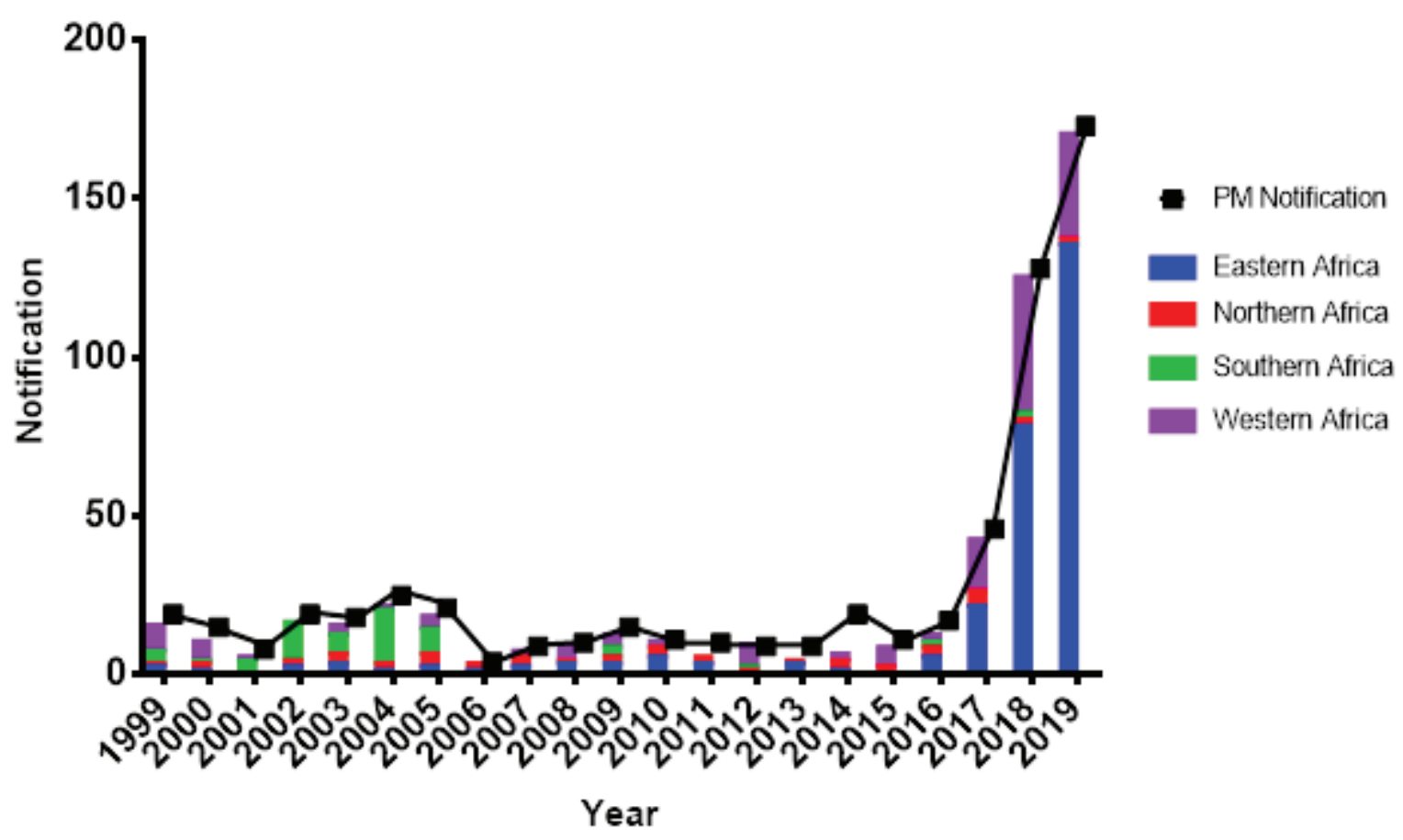

Figure 1: Trends of pathogenic microorganisms (PM) and Salmonella notifications in foods originating from different African regions from 1999 - 2019. Countries with Salmonella notifications in Eastern Africa were Ethiopia, Kenya, Madagascar, Mauritius, Sudan, Tanzania and Uganda; in Northern Africa were Egypt, Morocco and Tunisia; in Southern Africa were Botswana, Eswatini, Mozambique, Namibia, South Africa and Zimbabwe; and in Western Africa were Burkina Faso, Côte d'Ivoire, Ghana, Guinea, Mali, Niger, Nigeria and Senegal. 


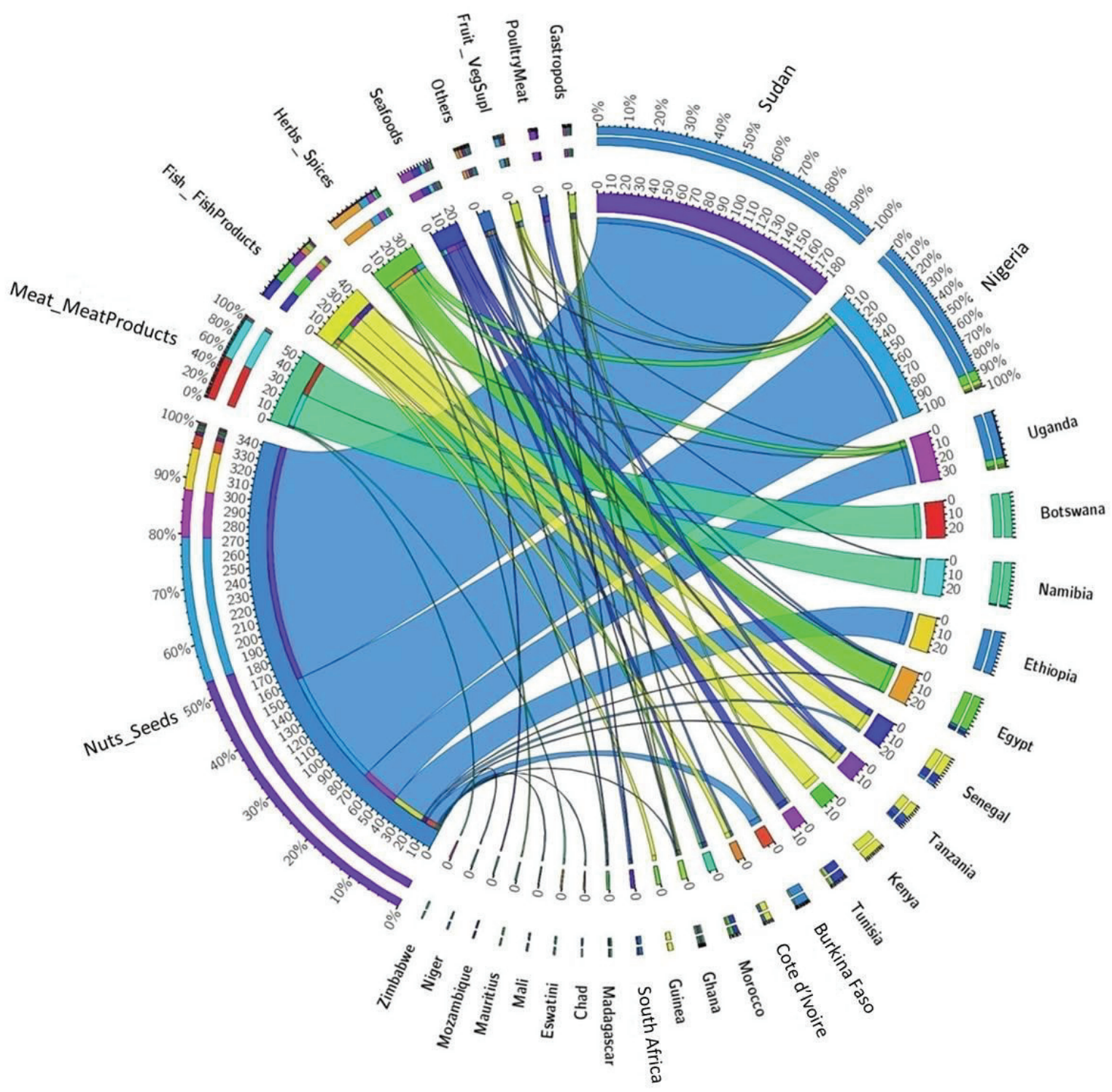

Figure 2: Product categories of RASFF Salmonella notifications in food products originating from African countries, by country of origin, 1999-2019. Arc lengths on the outer circle represent the percentage of notifications in each product category while those of the inner circles represent the number of notifications. 


\section{Highlights}

1. RASFF notifications of pathogenic microorganisms in food originating from Africa between 1999 and 2019 were analysed

2. 596 notifications were received from 19 countries regarding food from 27 African countries

3. Salmonella was the most predominant pathogen reported and accounted for $87.8 \%$ of the notifications

4. Most (64\%) Salmonella notification was reported in sesame seeds

5. There were few notifications of Campylobacter spp. $(n=2)$, L. monocytogenes $(n=1)$ and pathogenic $E$. coli $(\mathrm{n}=3)$. 